Elsevier Editorial System(tm) for Journal of Hazardous Materials

Manuscript Draft

Manuscript Number: HAZMAT-D-10-04375R2

Title: Desorption of Cadmium from a Natural Shanghai Clay Using Citric Acid Industrial Wastewater

Article Type: Research Paper

Keywords: Electrokinetic remediation; sorption; desorption; citric acid industrial wastewater (CAIW); MINTEQA2; soil remediation

Corresponding Author: Dr. Albert T. Yeung, PhD

Corresponding Author's Institution: University of Hong Kong

First Author: Ying-Ying Gu

Order of Authors: Ying-Ying Gu; Albert T. Yeung, PhD

Abstract: The sorption/desorption characteristics of heavy metals onto/from soil particle surfaces are the primary factor controlling the success of the remediation of heavy-metal contaminated soils. These characteristics are $\mathrm{pH}$-dependent, chemical-specific, and reversible; and can be modified by enhancement agents such as chelates and surfactants. In this study, batch experiments were conducted to evaluate the feasibility of using citric acid industrial wastewater (CAIW) to desorb cadmium from a natural clay from Shanghai, China at different soil mixture pHs. It can be observed from the results that the proportion of cadmium desorbed from the soil using synthesized CAIW is generally satisfactory, i.e., $>60 \%$, when the soil mixture $\mathrm{pH}$ is lower than 6 . However, the proportion of desorbed cadmium decreases significantly with increase in soil mixture $\mathrm{pH}$. The dominant cadmium desorption mechanism using CAIW is the complexion of cadmium with citric acid and acetic acid in CAIW. It is concluded that CAIW can be a promising enhancement agent for the remediation of cadmiumcontaminated natural soils when the environmental conditions are favorable. As a result, CAIW, a waste product itself, can be put into productive use in soil remediation. 


\title{
Desorption of Cadmium from a Natural Shanghai Clay \\ Using Citric Acid Industrial Wastewater
}

\author{
Ying-Ying Gu${ }^{1}$ and Albert T. Yeung, ${ }^{2, *}$
}

\begin{abstract}
Novelty Statement
The paper presents the results of an investigation on the potential use of citric acid industrial wastewater (CAIW) as an enhancement agent in electrokinetic remediation of cadmium contaminated high acid/base buffer capacity natural soil. The desorption characteristics of cadmium of a natural clay from Shanghai for a range of soil mixture $\mathrm{pH}$ values were evaluated experimentally. The information is vital for the use of CAIW as an enhancement agent for electrokinetic remediation, as the soil $\mathrm{pH}$ changes throughout the remediation process. Moreover, it establishes the viability of a productive use of a waste material to remediate cadmium contaminated high buffer capacity natural soil. The paper should be published in the Journal of Hazardous Materials as many readers of the journal are interested in soil remediation technologies.
\end{abstract}

\footnotetext{
* Corresponding author.
} 


\title{
Desorption of Cadmium from a Natural Shanghai Clay \\ Using Citric Acid Industrial Wastewater
}

\author{
Ying-Ying Gu ${ }^{1}$ and Albert T. Yeung, ${ }^{2, *}$
}

\section{Highlights}

- CAIW is very effective in desorbing cadmium from soil particle surfaces at soil mixture pHs of lower than 5 .

- The cadmium desorption efficiency of CAIW also depends on the initial sorbed concentration of cadmium on the soil particle surface.

- Complexion of cadmium with citric acid and acetic acid are the dominant mechanisms for cadmium desorption in the soil mixture $\mathrm{pH}$ range of 4 to 8 .

- CAIW may be a promising enhancement agent for the remediation of heavy metalcontaminated soils.

\footnotetext{
* Corresponding author.
} 


\title{
Desorption of Cadmium from a Natural Shanghai Clay
}

Using Citric Acid Industrial Wastewater

Ying-Ying $\mathrm{Gu}^{1}$ and Albert T. Yeung ${ }^{2, *}$

${ }^{1}$ Research Assistant Department of Civil Engineering The University of Hong Kong Pokfulam Road Hong Kong E-mail: guyhjlee@hkusua.hku.hk

${ }^{2}$ Associate Professor Department of Civil Engineering The University of Hong Kong Pokfulam Road Hong Kong E-mail: yeungat@hku.hk Phone: +85228598018 or +1 (925) 2859371 Fax: (852) 25595337

\begin{abstract}
The sorption/desorption characteristics of heavy metals onto/from soil particle surfaces are the primary factor controlling the success of the remediation of heavy-metal contaminated soils. These characteristics are pH-dependent, chemical-specific, and reversible; and can be modified by enhancement agents such as chelates and surfactants. In this study, batch experiments were conducted to evaluate the feasibility of using citric acid industrial wastewater (CAIW) to desorb cadmium from a natural clay from Shanghai, China at different soil mixture pHs. It can be observed from the results that the proportion of cadmium desorbed from the soil using synthesized CAIW is generally satisfactory, i.e., $>60 \%$, when the soil mixture $\mathrm{pH}$ is lower than 6 . However, the proportion of desorbed cadmium decreases
\end{abstract}

* Corresponding author. 

significantly with increase in soil mixture $\mathrm{pH}$. The dominant cadmium desorption mechanism using CAIW is the complexion of cadmium with citric acid and acetic acid in CAIW. It is concluded that CAIW can be a promising enhancement agent for the remediation of cadmium-contaminated natural soils when the environmental conditions are favorable. As a result, CAIW, a waste product itself, can be put into productive use in soil remediation.

\section{KEYWORDS: Electrokinetic remediation; sorption; desorption; citric acid industrial wastewater (CAIW); MINTEQA2; soil remediation \\ 1. INTRODUCTION}

Cadmium contamination of soil and groundwater is a worldwide environmental problem, posing threats on both public health and the environment. For example, vegetable cropland, paddy, and natural soils of many sites in Shanghai, China are contaminated by cadmium $[1,2]$. The natural concentration of cadmium in soil is between $0.1-1.0 \mathrm{mg} C \mathrm{Cd} / \mathrm{kg}$ soil and a cadmium concentration of higher than $10 \mathrm{mg}$ Cd/ $/ \mathrm{kg}$ soil can be toxic for plants [3]. Cadmium is a significant metal contaminant in the environment due to its high water solubility and toxicity [4], and its ability to cause itai-itai disease [5, 6].

When cadmium is sorbed on soil particle surfaces or precipitated, it is immobile and thus difficult to be extracted by most soil remediation technologies $[7,8]$. Therefore, an effective soil remediation technology must be able to transform and maintain cadmium in a mobile state to facilitate its removal from soil. Electrokinetic remediation of fine-grained soils has many advantages over many existing remediation technologies because an electrical gradient is a much more effective driving force in transporting fluid and chemical flows through fine-grained soils than a hydraulic gradient [7]. It applies a direct-current electric 
field across the contaminated soil through electrodes inserted into the contaminated soil. Contaminants are transported by electroosmosis, electromigration, and/or electrophoresis. Meanwhile, the fluids at the anode and cathode undergo electrolytic decomposition. An acidic environment is developed at the anode, favoring the solubilization of metal ions from soil particle surfaces. At the cathode, an alkaline environment is formed which enhances sorption of metals onto soil particle surfaces and precipitation of metallic oxides. Therefore, there is a need for an effective and economical technology to control the sorption/desorption characteristics of soil particle surfaces, so as to make the contaminant mobile to enhance the effectiveness of the remediation technology.

The sorption/desorption characteristics of soil particle surfaces are dynamic, $\mathrm{pH}$-dependent, and reversible. In general, keeping a low $\mathrm{pH}$ environment in soil enhances the extractability of heavy metals. However, achieving an acidic environment may be difficult for natural soils of high acid buffer capacity [9, 10]. Nonetheless, the sorption/desorption characteristics of soil particle surfaces can be modified by the use of enhancement agents including chelates, surfactants, organic acids, etc. [6, 9, 11-13]. Among these enhancement agents, EDTA has been demonstrated to be one of the most effective in desorbing heavy metals from soils of high buffer capacity $[6,9,11,14]$. The injection of EDTA into contaminated Milwhite kaolinite effectively desorbs lead and cadmium from soil particle surfaces and mobilizes them during electrokinetic extraction $[6,11,13,15]$. However, the high cost and non-selective nature of EDTA have limited its use in the remediation of metal-contaminated sites $[16,17]$. Moreover, EDTA resists biodegradation and can be sorbed on soil particle surfaces. As a result, soils remediated by EDTA or similar chelating agents may not be suitable for future agricultural use $[18,19]$.

In this study, citric acid industrial wastewater (CAIW) was studied as a potential cost-effective enhancement agent for electrokinetic remediation of metal-contaminated soils, 
so as to put a waste product into effective and economical use. However, the $\mathrm{pH}$ of the contaminated soil may be changed by the electrokinetic remediation process as a function of time and space. Therefore, a comprehensive study of the performance of CAIW at different soil mixture pHs was conducted in this study.

CAIW is a recalcitrant dark-colored wastewater of low $\mathrm{pH}$ containing large quantities of citric acid, acetic acid, and other impurities. Although many techniques have been developed for the treatment of CAIW [20-22], effective and economical disposal of the large quantity of CAIW being produced routinely remains a challenge. As weak organic acids and heavy metal chelates, citric acid and acetic acid have been used successfully to promote efficient removal of heavy metals from soils $[14,18,19,23-25]$. CAIW was also used as the chelating agent in the phytoremediation of heavy metal contaminated soils by Chen et al. [26]. Their results indicate that CAIW is effective in improving the availability of different forms of copper in the contaminated soil for the plant, although it is still less efficient than EDTA. However, the potential application of CAIW in electrokinetic remediation technology as an enhancement agent has yet to be studied. Therefore, the study presented in this paper was conducted.

CAIW may be a cost-effective chelating agent source in lieu of commercial citric acid and acetic acid so as to put a waste product to a productive use. As weak organic acids, they would not lower the soil $\mathrm{pH}$ to a level detrimental to the environment [27]. Moreover, a very low soil $\mathrm{pH}$ may reverse the electroosmotic flow direction, thus reducing the efficiency of electrokinetic remediation of metal-contaminated soils [6]. Therefore, CAIW may serve as an efficient and economical enhancement agent in electrokinetic remediation of cadmium-contaminated fine-grained soil.

In this study, batch experiments were conducted to extract cadmium from a natural clay soil from Shanghai, China. Effects of soil mixture $\mathrm{pH}$, initial sorbed concentration of 
cadmium on the soil particle surface, and CAIW concentration on cadmium desorption from

108 clay particle surfaces were studied. Moreover, desorption tests using different individual constituents of CAIW were carried out to evaluate their individual contribution towards the 110 desorption ability of CAIW.

\section{MATERIALS AND METHODS}

\subsection{Materials}

\subsubsection{Soil}

The soil used in this study is a natural clay soil collected at depths of $0.5-1.0 \mathrm{~m}$ in Nanhui District, Shanghai, China. The soil was air-dried, pulverized, screened through a 2-mm opening sieve, homogenized, autoclaved for 120 minutes, and then stored for later use. The soil was autoclaved to remove the microorganisms in the soil to eliminate possible biodegradation of any chemical in the system, so as to avoid misinterpretation of the results. The soil is classified as CL, i.e., inorganic clays of low to medium plasticity, in accordance with the Unified Soil Classification System [28]. In fact, it is a slightly alkaline clay soil of low plasticity. The background concentration of cadmium in the soil is negligible relative to the cadmium concentration to be spiked into the soil in this study. Physicochemical properties of the soil are tabulated in Table 1 and more details are given in Gu et al. [9].

\subsubsection{Citric Acid Industrial Wastewater (CAIW)}

Citric acid industrial wastewater (CAIW) is a dark-colored waste liquid of low $\mathrm{pH}$ containing large quantities of organic acids and other impurities [29]. It is the wastewater generated by the manufacturing process of citric acid. The CAIW used in this study was synthesized in the laboratory and its properties are tabulated in Table 1. The CAIW was synthesized so that its chemical composition is representative of most real-life CAIW. 
132 HoweverMoreover, the well-defined chemical composition of the synthesized CAIW can 133 facilitate interpretation of the experimental results and repeatability of the study.

\section{$135 \quad 2.2 \quad$ Experimental Procedures}

136 Different series of batch experiments were conducted to evaluate the desorption 137 characteristics of CAIW by systematically varying the experimental parameters and 138 procedures as described.

\subsubsection{Desorption Edge using CAIW}

Desorption edge experiments were conducted following the method described by 142 Torrens et al. [30]. One gram of soil specimen and $10 \mathrm{~mL}$ of $0.5,1,2,3,4$, or $5 \mathrm{mM}$ $143 \mathrm{Cd}\left(\mathrm{NO}_{3}\right)_{2}$ solution were added to a $50-\mathrm{mL}$ centrifuge. The soil mixtures were shaken for 14424 hours using a wrist action shaker at $25^{\circ} \mathrm{C}$ to allow cadmium to sorb on soil particle 145 surfaces before they were centrifuged at 4,000 rpm for 15 minutes. The centrifuge tubes 146 containing the mixtures were then weighed before and after the supernatants were decanted to 147 determine the volume of cadmium solution retained in the soil. Cadmium concentration in the 148 supernatant was diluted with $1 \% \mathrm{HNO}_{3}$ and measured using a Perkin Elmer Analyst 300 149 flame atomic absorption spectrometer. The sorbed concentration of cadmium on the soil 150 particle surface was thus determined.

151 Afterwards, $10 \mathrm{~mL}$ of synthesized CAIW was added to each soil mixture to serve as 152 the purging solution. A control test was also conducted using $10 \mathrm{~mL}$ of deionized water in 153 lieu of CAIW. The $\mathrm{pHs}$ of the-soil mixture $\mathrm{pH}$ s were adjusted to different values by adding 1540.1 and/or $1 \mathrm{M} \mathrm{HNO}_{3}$ or 0.1 and/or $1 \mathrm{M} \mathrm{NaOH}$. The adjusted $\mathrm{pH}$ of the soil mixture was 155 measured by a pH meter. The soil mixtures were shaken for 5 hours and then centrifuged. The 156 supernatant was diluted with $1 \% \mathrm{HNO}_{3}$ and analyzed for cadmium concentration using 

168

atomic absorption spectrometry to determine the quantity of cadmium desorbed. Each test was performed in duplicate to ensure repeatability of the experiments.

\subsubsection{Effect of CAIW Concentration on Cadmium Desorption}

Two milliliters of $2.5 \mathrm{mM} \mathrm{Cd}\left(\mathrm{NO}_{3}\right)_{2}$ solution was added to each 1-g dry soil specimen 162 and the soil mixture was shaken for 24 hours to allow cadmium to sorb onto soil particle

water. The $\mathrm{pH}$ of the-soil mixture $\mathrm{pH}$ was adjusted to 5.3 by adding $1 \mathrm{M} \mathrm{HNO}_{3}$. The soil

\subsubsection{Effects of Individual CAIW Constituents on Cadmium Desorption}

CAIW contains large quantities of organic acids and other ions such as $\mathrm{Cl}^{-}, \mathrm{SO}_{4}{ }^{2-}$, $\mathrm{Ca}^{2+}$, and $\mathrm{NH}_{4}^{+}$. These constituents may affect desorption of cadmium from soil particle surfaces differently. In this series of desorption experiments, purging solutions of deionized water, synthesized CAIW, or individual constituents of CAIW, including $2.96 \mathrm{~g} / \mathrm{L}$ of $\mathrm{Na}_{2} \mathrm{SO}_{4}$, $1.4 \mathrm{~g} / \mathrm{L}$ of $\mathrm{CaCl}_{2}, 0.134 \mathrm{~g} / \mathrm{L}$ of $\mathrm{NH}_{4} \mathrm{Cl}, 3 \mathrm{~g} / \mathrm{L}$ of citric acid, and $5.5 \mathrm{~g} / \mathrm{L}$ of acetic acid, were prepared to evaluate their individual effects on desorption of cadmium from the natural clay.

Two milliliters of $2.5 \mathrm{mM} \mathrm{Cd}\left(\mathrm{NO}_{3}\right)_{2}$ solution of was added to $1 \mathrm{~g}$ of soil placed in a 50-mL centrifuge tube and shaken for 24 hours to allow cadmium to sorb on soil particle surfaces. Afterwards, $8 \mathrm{~mL}$ of the purging solution was added to each mixture. The $\mathrm{pHs}$ of the soil mixture $\underline{\mathrm{pH}} \mathrm{s}$ were adjusted by addition of 0.1 and/or $1 \mathrm{M} \mathrm{HNO}_{3}$ or 0.1 and/or $1 \mathrm{M} \mathrm{NaOH}$ 
and the adjusted $\mathrm{pH}$ was measured by a $\mathrm{pH}$ meter. After 5 hours of shaking, the soil mixtures were centrifuged and the supernatants were diluted with $1 \% \mathrm{HNO}_{3}$ for determination of cadmium concentration.

\section{RESUlTS AND DisCUSSION}

\subsection{Desorption Edge}

The effects of CAIW on desorption of cadmium from soil at different soil mixture $\mathrm{pH}$ values are compared to those of deionized water in Figure 1. Ten milliliters of $0.5 \mathrm{mM}$

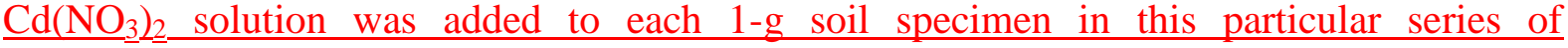
experiments, and tThe resulting initial sorbed concentration of cadmium on soil particle surfaces in this series of experiments was measured to be $530 \mathrm{mg} \mathrm{Cd} / \mathrm{kg}$ soil. It can be observed that deionized water can desorb approximately $40 \%$ of cadmium from soil particle surfaces at soil mixture $\mathrm{pH} 5$. When the soil mixture $\mathrm{pH}$ is increased to 7, desorption of cadmium from soil becomes less than $2 \%$. However, with the addition of CAIW, the proportion of desorbed cadmium is increased to more than $85 \%$ at soil mixture $\mathrm{pH} 5$. In the soil mixture $\mathrm{pH}$ range of 5 to 8 , CAIW increases the proportions of desorbed cadmium by $20 \%$ to $45 \%$ more than those by deionized water at the same soil mixture pHs. Furthermore, the upper bound of soil mixture $\mathrm{pH}$ limit for cadmium desorption is extended from 7 to 10 . The results indicate the ability of CAIW to solubilize the cadmium sorbed on soil particle surfaces is considerably better than that of deionized water.

Desorption curves of cadmium using CAIW of different initial sorbed concentrations are depicted in Figure 2. The drastic influence of soil mixture $\mathrm{pH}$ on desorption of cadmium from soil particle surfaces at all initial sorbed concentrations of cadmium on the soil particle surface is evidently demonstrated. At soil mixture pHs lower than 5, the proportion of cadmium desorbed from soil by CAIW is very high, i.e., > 85\%. However, the proportion 
decreases significantly with increase in soil mixture $\mathrm{pH}$ when the soil mixture $\mathrm{pH}$ is greater than 5. However, the decrease in proportion of cadmium desorbed per unit increase in soil mixture $\mathrm{pH}$ is practically independent of the initial sorbed concentration. When the soil mixture $\mathrm{pH}$ is further increased to a threshold value in the range of 9.5 to 11.5 , the proportion of cadmium desorbed becomes negligible. The threshold soil mixture $\mathrm{pH}$ depends on the initial sorbed concentration. The higher is the initial sorbed concentration, the higher is the threshold soil mixture $\mathrm{pH}$.

It can also be observed that the proportion of cadmium desorbed increases with the initial sorbed concentration of cadmium on the soil particle surface. The phenomenon is more prominent when the soil mixture $\mathrm{pH}$ is higher than 5 . When the initial sorbed cadmium concentration is low, cadmium ions are primarily sorbed onto high selectivity sorption sites. However, cadmium ions are getting sorbed onto low selectivity cation exchange sites when the initial sorbed cadmium concentration is increased. As a result, the increase in cadmium density on soil particle surfaces favors the cation exchange process by $\mathrm{NH}_{4}{ }^{+}, \mathrm{Ca}^{2+}$, etc. in CAIW, thus increasing the proportion of cadmium desorbed. In a high $\mathrm{pH}$ environment, the surface charges on soil particles become more negative as indicated by the zeta potential of the soil particle surface, leading to an enhancement of specific sorption of heavy metals [9, 31]. Moreover, precipitation of insoluble cadmium hydroxides and cadmium carbonates makes desorption more difficult.

\subsection{Effect of CAIW Concentration on Cadmium Desorption}

The effect of CAIW concentration on cadmium desorption at $\mathrm{pH} 5$ is shown in Figure

3. The relative concentration of CAIW is defined to be the diluted concentration of CAIW used in the experiment normalized byrelative te the original concentration of the synthesized CAIW. Deionized water alone can only desorb $24.7 \%$ of cadmium sorbed on the soil particle 
surface at soil mixture $\mathrm{pH}$ 5. The addition of CAIW increases the proportion of cadmium desorbed. The higher is the relative concentration of CAIW, the higher is the proportion of cadmium desorbed from the soil. However, the increase in the proportion of cadmium desorbed per unit increase in relative concentration of CAIW decreases with increase in relative concentration of CAIW. Nonetheless, CAIW of relative concentration of 0.8 can desorb more than $80 \%$ of the sorbed cadmium from the soil, indicating the original concentration of CAIW is adequate to function as an enhancement agent to desorb cadmium from soil satisfactorily at soil mixture $\mathrm{pH}$. Therefore, CAIW can be used as it is produced without much processing.

\subsection{Contributions of Individual Constituents of CAIW to Cadmium Desorption}

The results of cadmium desorption using individual constituents of CAIW at different soil mixture pHs are depicted in Figure 4. It can be observed that citric acid is the most efficient purging solution followed by acetic acid, indicating desorption of cadmium from soil by CAIW can be mostly attributed to the presence of citric acid and acetic acid. Citric acid is a weak triprotic acid which can form mononuclear, binuclear, or polynuclear and bi-, tri-, and multidentate complexes with heavy metals, depending on the type of metallic ion [32]. Acetic acid is a low-weight organic acid which can form soluble monodentate complexes with heavy metals. The higher stability of citrate-cadmium complexes leads to the higher efficiency of citric acid in desorbing cadmium from soils than acetic acid, as observed in the tabulated stability constants of cadmium complexes in Table 2 .

The enhancing effects of weak organic acids on desorption of heavy metal have been studied by many researchers [14, 17, 33-37]. However, most of these studies use these low molecular weight organic acids as a conditioning solution to lower the soil mixture $\mathrm{pH}$ but do not investigate in detail the effects of soil mixture $\mathrm{pH}$ on the desorption efficiency of heavy 
metals from soil. 265

Other ionic species in CAIW also enhance the extraction of cadmium from the soil. $\mathrm{NH}_{4}{ }^{+}, \mathrm{SO}_{4}{ }^{2 \square}$, and $\mathrm{Cl}^{\square}$ have a slight ability to desorb cadmium from soil by forming complexes with cadmium, such as $\mathrm{Cd}\left(\mathrm{NH}_{3}\right)_{4}{ }^{2+}, \mathrm{CdSO}_{4}, \mathrm{CdCl}^{+}$and $\mathrm{CdCl}_{2}$. Cations such as $261 \mathrm{Ca}^{2+}$ and $\mathrm{Na}^{+}$can enhance the solubilization of cadmium at lower soil mixture pHs by 262 competing for sorption sites on soil particle surfaces with cadmium ions [38].

263 Cadmium desorption by different constituents of CAIW is pH-dependent. Cadmium 264 extractability from soil decreases when the soil mixture $\mathrm{pH}$ is increased from 5 to 9 . The results are in good agreement with those of many previous studies. Naidu and Harter [39] 266 reported that desorption of cadmium using organic ligands including acetate and citrate 267 decreased with increase in soil mixturethe $\mathrm{pH}$ of the ligand solution. Yuan et al. [37] observed 268 that desorption of cadmium by citric acid decreased sharply with increase in soil mixture $\mathrm{pH}$. Mustafa et al. [37] demonstrated experimentally that an increase in equilibrium soil mixture $270 \mathrm{pH}$ from 5.5 to 6.0 can reduce cadmium desorption from goethite using $\mathrm{Ca}\left(\mathrm{NO}_{3}\right)_{2}$ 271 significantly.

However, opposite results revealed by some other studies indicate that metal 273 desorption by citric acid decreased at low soil mixture $\mathrm{pHs}[40,41]$. The difference can be soil particle surfaces into the solution phase. from soil particle surfaces using citric acid is much higher than those using other constituents 
of CAIW, probably due to complexion of cadmium with citric acid. As the $\mathrm{pK}_{\mathrm{a}}$ values of 283 citric acid are $3.13,4.76$, and 6.40 , the ratio of $[\text { Citrate] }]^{3-}$ increases significantly and 284 dominates at soil mixture pHs of higher than 7.0, accounting for the high desorption rate of 285 cadmium from soil particle surfaces. However, the logarithmic stability constant of $286 \mathrm{Cd}[\text { Citrate }]^{-}$, i.e., 11.3 , is less than the solubility of $\mathrm{Cd}(\mathrm{OH})_{2}\left(\mathrm{pK}_{\mathrm{sp}}=13.6\right)$, resulting in 287 precipitation of cadmium with $\mathrm{OH}^{-}$with increase in soil mixture $\mathrm{pH}$ [37].

\section{CONCLUSIONS}

Several conclusions can be drawn from this experimental study on desorption of cadmium from a natural Shanghai clay using synthesized CAIW: 
a. CAIW is very effective in desorbing cadmium from soil particle surfaces at soil

mixture pHs of lower than 5. However, the proportion of cadmium desorbed decreases significantly with increase in soil mixture $\mathrm{pH}$. When the soil mixture $\mathrm{pH}$ is higher than a threshold value, the proportion of cadmium that can be desorbed becomes negligible. The threshold soil mixture $\mathrm{pH}$ increases with initial sorbed concentration of cadmium on the soil particle surface.

b. The cadmium desorption efficiency of CAIW also depends on the initial sorbed concentration of cadmium on the soil particle surface. The proportion of cadmium desorbed increases with increase in initial sorbed concentration.

c. Complexion of cadmium with citric acid and acetic acid are the dominant mechanisms for cadmium desorption in the soil mixture $\mathrm{pH}$ range of 4 to 8 . At higher soil mixture pHs, precipitated cadmium is difficult to be desorbed.

d. CAIW may be a promising enhancement agent for the remediation of heavy metal-contaminated soils. The use of CAIW as an enhancement agent can put the waste product to a productive use.

\section{REFERENCES}

[1] G. Shen, Z. Xie, X. Qian, L. Huang, C. Guo, M. Wang, Z. Shan, Investigation and analysis of heavy metal accumulation in the soil of vegetable cropland in Shanghai, $J$. Agro-environ. Sci. 25 (2006) 37-40 (in Chinese).

[2] C. Yao, Z. Chen, J. Zhang, J. Hou, Heavy metal pollution assessment of vegetables in Pudong zone of Shanghai, J. Agro-environ. Sci. 24 (2005) 761-765 (in Chinese).

329 [3] S. Palagyi, P. Salzer, A. Mitro, Sorption, desorption and extraction of cadmium from $330 \quad$ some arable and forest soils, J. Radioanal. Nuclear Chem. 269 (2006) 103-113.

331 [4] A.P.M. Lockwood (editor), Effects of Pollutants on Aquatic Organisms, Cambridge 
University Press, New York, 1976.

[5] K. Nogawa, T. Kido, Biological monitoring of cadmium exposure in itai-itai disease epidemiology, Int. Archives Occup. Environ. Health 65 (1993) S43-S46.

[6] A.T. Yeung, C. Hsu, Electrokinetic remediation of cadmium-contaminated clay, J. Environ. Eng., ASCE 131 (2005) 298-304.

[7] A.T. Yeung, Contaminant extractability by electrokinetics, Environ. Eng. Sci. 23 (2006) 202-224.

[8] A.T. Yeung, Remediation technologies for contaminated sites, in: Chen, Y., Tang, X., Zhan, L. (Eds.), Advances in Environmental Geotechnics, Zhejiang University Press, Hangzhou, 2009, pp. 328-369.

[9] Y.-Y. Gu, A.T. Yeung, A. Koenig, H.-J. Li, Effects of chelating agents on zeta potential of cadmium-contaminated natural clay, Sep. Sci. Technol. 44 (2009) 2203-2222.

[10] J. Virkutyte, M. Sillanpaa, P. Latostenmaa, Electrokinetic soil remediation - critical overview, Sci. Total Environ. 289 (2002) 97-121.

[11] A.T. Yeung, C. Hsu, R.M. Menon, EDTA-enhanced electrokinetic extraction of lead, J. Geotech. Eng., ASCE 122 (1996) 666-673.

[12] K.R. Reddy, C. Chaparro, R.E. Saichek, Removal of mercury from clayey soils using electrokinetics, J. Environ. Sci. Health Part A - Toxic/Hazard. Subst. Environ. Eng. 38 (2003) 307-338.

[13] J.S.H. Wong, R.E. Hicks, R.F. Probstein, EDTA-enhanced electroremediation of metal-contaminated soils, J. Hazard. Mater. 55 (1997) 61-79.

[14] A. Giannis, E. Gidarakos, Washing enhanced electrokinetic remediation for removal cadmium from real contaminated soil, J. Hazard. Mater. 123 (2005) 165-175.

[15] C. Hsu, Electrokinetic Remediation of Heavy Metal Contaminated Soils. Ph.D. thesis, Department of Civil Engineering, Texas A\&M University, College Station, 1997. 
[16] A. Barona, I. Aranguiz, A. Elias, Metal associations in soils before and after EDTA extractive decontamination: implications for the effectiveness of further cleanup procedures, Environ. Pollut. 113 (2001) 79-85.

[17] E. Gidarakos, A. Giannis, Chelate agents enhanced electrokinetic remediation for removal cadmium and zinc by conditioning catholyte pH, Water Air Soil Pollut. 172 (2006) 295-312.

[18] S.A. Wasay, S.F. Barrington, S. Tokunaga, Remediation of soils polluted by heavy metals using salts of organic acids and chelating agents, Environ. Technol. 19 (1998) 369-379.

[19] S.A. Wasay, S. Barrington, S. Tokunaga, Organic acids for the in situ remediation of soils polluted by heavy metals: Soil flushing in columns, Water Air Soil Pollut. 127 (2001) 301-314.

[20] V. O'Flahertya, P. Lensa, B. Leahyb, E. Colleran, Long-term competition between sulphate-reducing and methane-producing bacteria during full-scale anaerobic treatment of citric acid production wastewater, Water Res. 32 (1998) 815-825.

[21] A.J.M. Stams, J. Huisman, P.A.G. Encina, G. Muyzer, Citric acid wastewater as electron donor for biological sulfate reduction, Appl. Microbiol. Biotechnol. 83 (2009) 957-963.

[22] H. Yang, P. Shao, T. Lu, J. Shen, D. Wang, Z. Xu, X. Yuan, Continuous bio-hydrogen production from citric acid wastewater via facultative anaerobic bacteria, Int. J. Hydrogen Energy, 31 (2006) 1306-1313.

[23] I. F. Poulsen, H.C.B. Hansen, Soil sorption of nickel in presence of citrate or arginine, Water, Air Soil Pollut. 120 (2000) 249-259.

[24] S.K. Puppala, A.N. Alshawabkeh, Y.B. Acar, R.J. Gale, M. Bricka, Enhanced electrokinetic remediation of high sorption capacity soil, J. Hazard. Mater. 55 (1997) 
203-220.

[25] T. Vengris, R. Binkiene, A. Sveikauskaite, Electrokinetic remediation of lead-, zinc- and cadmium-contaminated soil, J. Chem. Technol. Biotechnol. 76 (2001) 1165-1170.

[26] Y.X. Chen, J.Y. Shi, W.D. Zhang, Q. Lin, G.M. Tian, EDTA and industrial waste water improving the bioavailability of different $\mathrm{Cu}$ forms in contaminated soil, Plant Soil 261 (2004) $117-125$.

[27] Y. Hirano, N. Hijii, Effects of low pH and aluminum on root morphology of Japanese red cedar saplings, Environ. Pollut. 101 (1998) 339-347.

[28] American Society for Testing and Materials, Standard Practice for Classification of Soils for Engineering Purposes (Unified Soil Classification System), ASTM Standard D2487-10, ASTM International, West Conshohocken, 2010.

[29] D.R. Wilson, I.C. Page, A.A. Cocci, R.C. Landine, Case history - Two stage, low-rate anaerobic treatment facility for South American alcochemical citric acid wastewater, Water Sci. Technol. 38 (1998) 45-52.

[30] J.L. Torrens, D.C. Herman, R.M. Miller-Maier, Biosurfactant (Rhamnolipid) sorption and the impact on Rhamnolipid-facilitated removal of cadmium from various soils under saturated flow conditions, Environ. Sci. Technol. 32 (1998) 776-781.

[31] G. Sposito, The Chemistry of Soils, second ed., Oxford University Press, Oxford, 2008.

[32] A.J. Francis, C.J. Dodge, J.B. Gillow, Biodegradation of metal citrate complexes and interactions for toxic metal mobility, Nature 356 (1992) 140-142.

[33] R. Bassi, S.O. Prasher, B.K. Simpson, Extraction of metals from a contaminated sandy soil using citric acid, Environ. Prog. 19 (2000) 275-282.

[34] S.R. Burckhard, A.P. Schwab, M.K. Banks, The effects of organic acids on the leaching of heavy metals from mine tailings, J. Hazard. Mater. 41 (1995) 135-145.

[35] H.S. Lee, K. Lee, S.S. Kim, S.H. Ko, Effects of soil buffering capacity and citric acid in 
407 electrolyte on electrokinetic remediation of mine tailing soils, J. Ind. Eng. Chem. 9 $408 \quad$ (2003) 360-365.

[36] A. Polettini, R. Pomi, E. Rolle, The effect of operating variables on chelant-assisted remediation of contaminated dredged sediment, Chemosphere 66 (2007) 866-877.

[37] S.H. Yuan, Z.M. Xi, Y. Jiang, J.Z. Wan, C. Wu, Z.H. Zheng, X.H. Lu, Desorption of copper and cadmium from soils enhanced by organic acids, Chemosphere 68 (2007) $1289-1297$.

[38] G. Mustafa, R.S. Kookana, B. Singh, Desorption of cadmium from goethite: Effects of pH, temperature and aging, Chemosphere 64 (2006) 856-865.

[39] R. Naidu, R.D. Harter, Effect of different organic ligands on cadmium sorption by and extractability from soils, Soil Sci. Soc. Am. J. 62 (1998) 644-650.

[40] P. Chairidchai, G.S.P. Ritchie, The effect of $\mathrm{pH}$ on zinc adsorption by a lateritic soil in the presence of citrate and oxalate, J. Soil Sci. 43 (1992) 723-728.

[41] Y.X. Chen, Q. Lin, Y.M. Luo, Y.F. He, S.J. Zhen, Y.L. Yu, G.M. Tian, M.H. Wong, The role of citric acid on the phytoremediation of heavy metal contaminated soil, Chemosphere 50 (2003) 807-811.

[42] N.A. Lange, Lange's Handbook of Chemistry, 16th ed., McGraw-Hill, New York, 2005. 


\section{List of Tables}

Table 2. Accumulative for

428

429

$430 \quad$ List of Figures

431 Figure 1. Comparison of cadmium desorption by CAIW and deionized water

432 Figure 2. Desorption of cadmium of different initial sorbed concentrations by CAIW

[42]
433 Figure 3. Effect of CAIW concentration on cadmium desorption
434 Figure 4. Effect of individual constituents of CAIW on cadmium desorption
435 Figure 5. Concentrations of different species in CAIW-Cd (0.5 mM) system by MINTEQA2

Table 2. Accumulative formation constants of cadmium complexes with citrate and acetate

(1)




\begin{tabular}{l|c}
\hline \multicolumn{1}{c|}{ Property } & Value \\
\hline \hline Soil & \\
\hline \multicolumn{1}{c}{ Specific gravity } & 2.73 \\
Liquid limit (\%) & 36 \\
Plastic limit (\%) & 19 \\
Plasticity index (\%) & 17 \\
pH (1:1) & 8.29 \\
Organic content $(\%)$ & $0.18 \%$ \\
Electrical conductivity $(\mathrm{dS} / \mathrm{cm})$ & 0.339 \\
Cd concentration $(\mathrm{mg} / \mathrm{kg})$ & 1.6 \\
\hline \hline
\end{tabular}

\section{Synthesized CAIW}

\begin{tabular}{c|c}
\hline $\mathrm{pH}$ & 3.87 \\
Concentration of citric acid $(\mathrm{mg} / \mathrm{L})$ & 3000 \\
Concentration of Acetic acid $(\mathrm{mg} / \mathrm{L})$ & 5500 \\
Concentration of $\mathrm{SO}_{4}{ }^{2-}(\mathrm{mg} / \mathrm{L})$ & 2001.1 \\
Concentration of $\mathrm{Ca}^{2+}(\mathrm{mg} / \mathrm{L})$ & 504.5 \\
Concentration of $\mathrm{Cl}^{-}(\mathrm{mg} / \mathrm{L})$ & 984.4 \\
Concentration of $\mathrm{NH}_{4}{ }^{+}(\mathrm{mg} / \mathrm{L})$ & 45.1 \\
Concentration of $\mathrm{Na}^{+}(\mathrm{mg} / \mathrm{L})$ & 958.9 \\
\hline
\end{tabular}


Table 2. Accumulative formation constants of cadmium complexes with citrate and acetate [42]

\begin{tabular}{c|c}
\hline Cd Complexes & Accumulative Formation Constants \\
\hline $\mathrm{CdH}_{2}(\text { Citrate })^{+}$ & 7.9 \\
$\mathrm{CdH}($ Citrate $)$ & 3.05 \\
$\mathrm{Cd}(\text { Citrate })^{-}$ & 3.10 \\
\hline $\mathrm{Cd}(\text { Acetate })^{+}$ & 1.5 \\
$\mathrm{Cd}(\text { Acetate })_{2}$ & 2.3 \\
$\mathrm{Cd}(\text { Acetate })_{3}{ }^{-}$ & 2.4 \\
\hline where $\quad($ Citrate $)=\mathrm{C}_{3} \mathrm{H}_{5} \mathrm{O}\left(\mathrm{COO}_{3}{ }_{3}^{3-}\right.$ & \\
\hline
\end{tabular}

3 


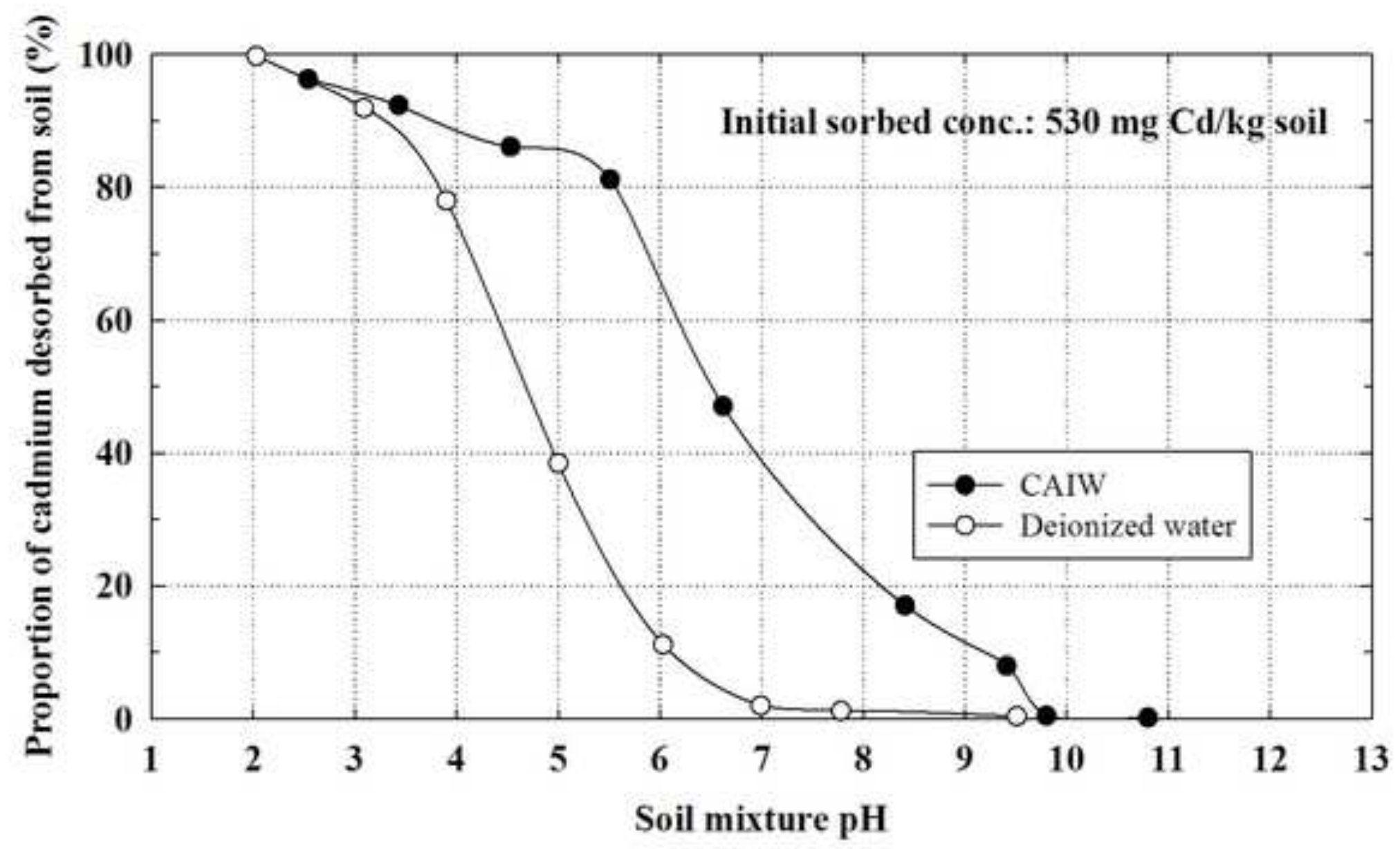

Figure 1. Comparison of cadmium desorption by CAIW and deionzed water 


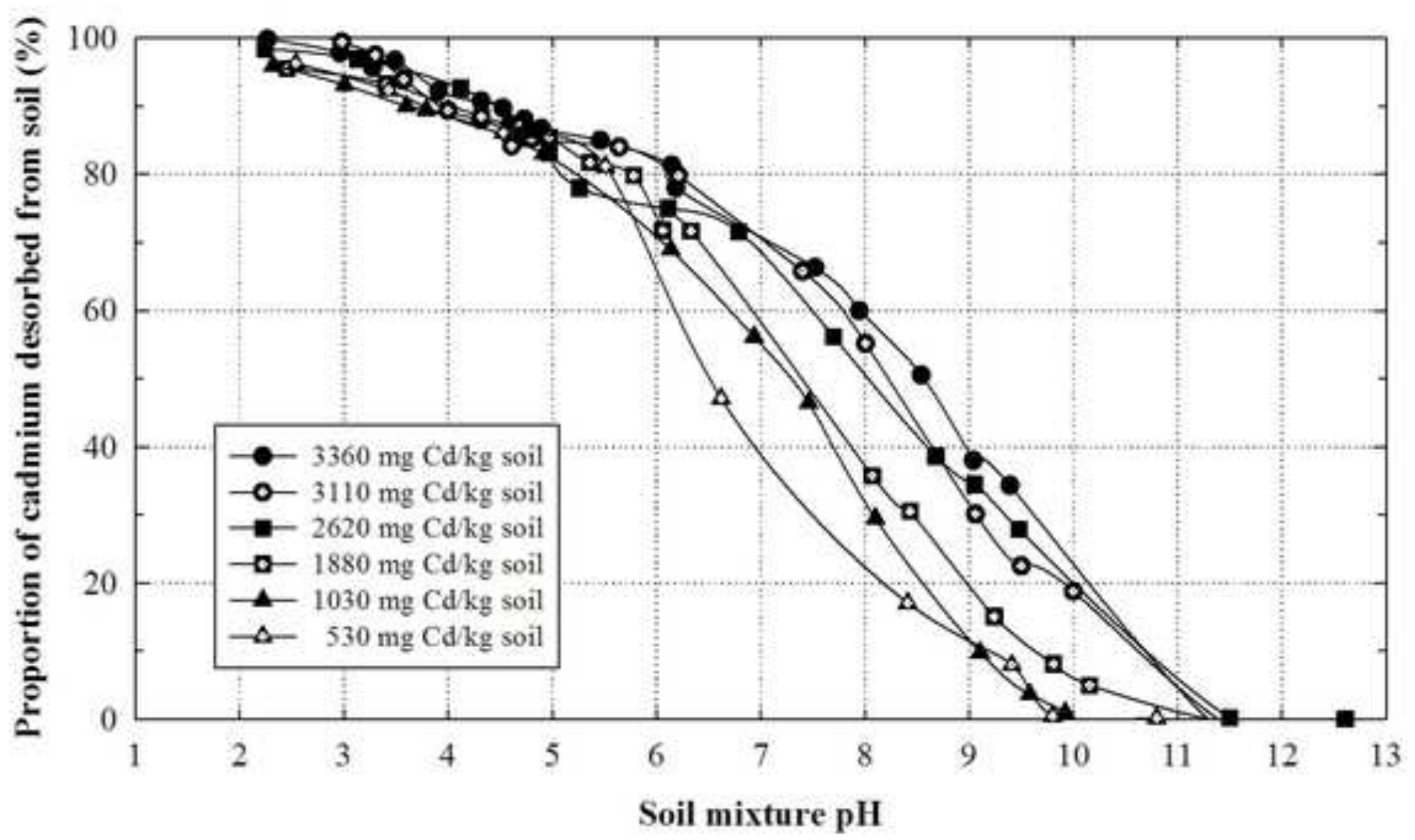

Figure 2. Desorption of cadmium of different initial sorbed concentrations by CAIW 


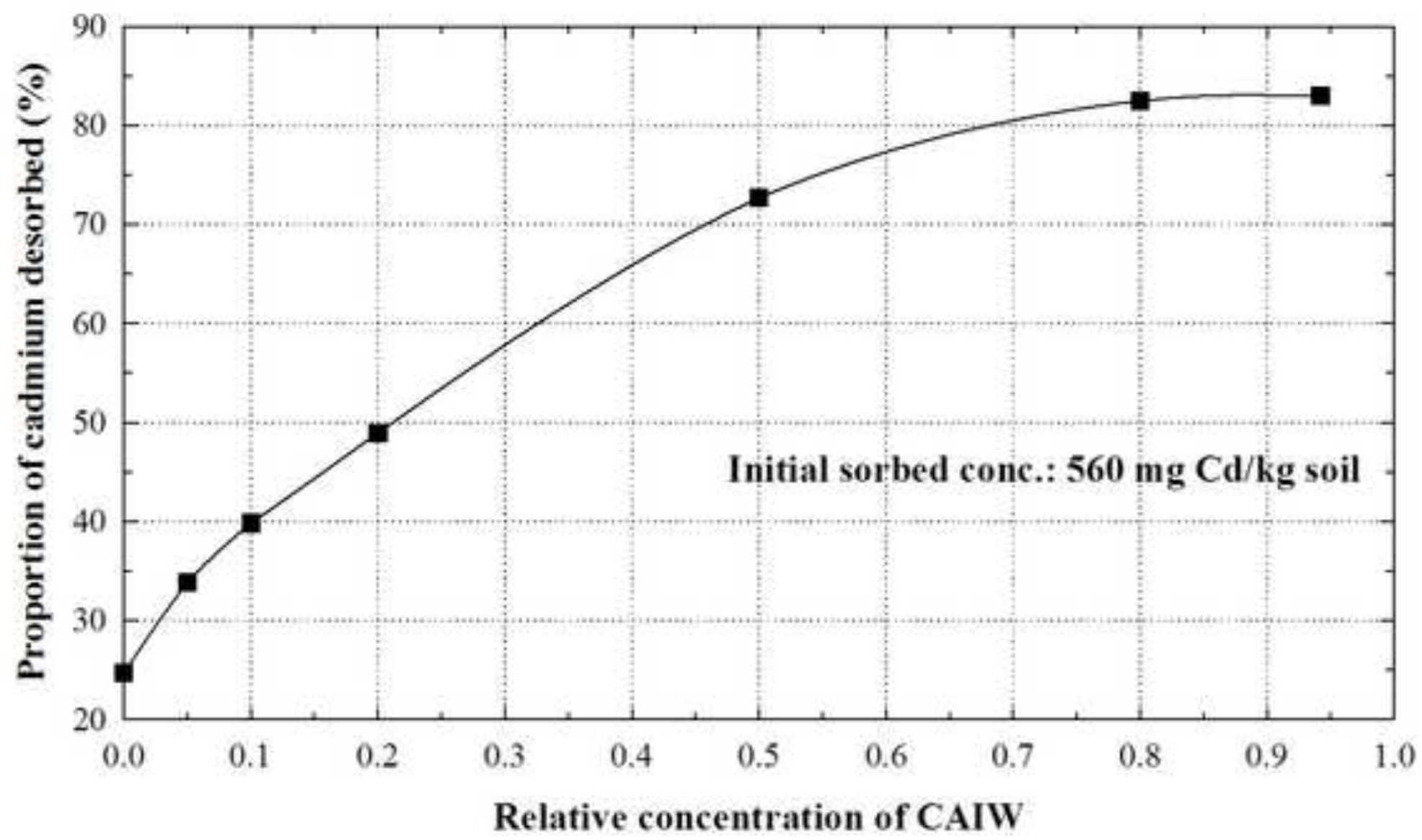

Figure 3. Effect of CAIW concentration on cadmium desorption 


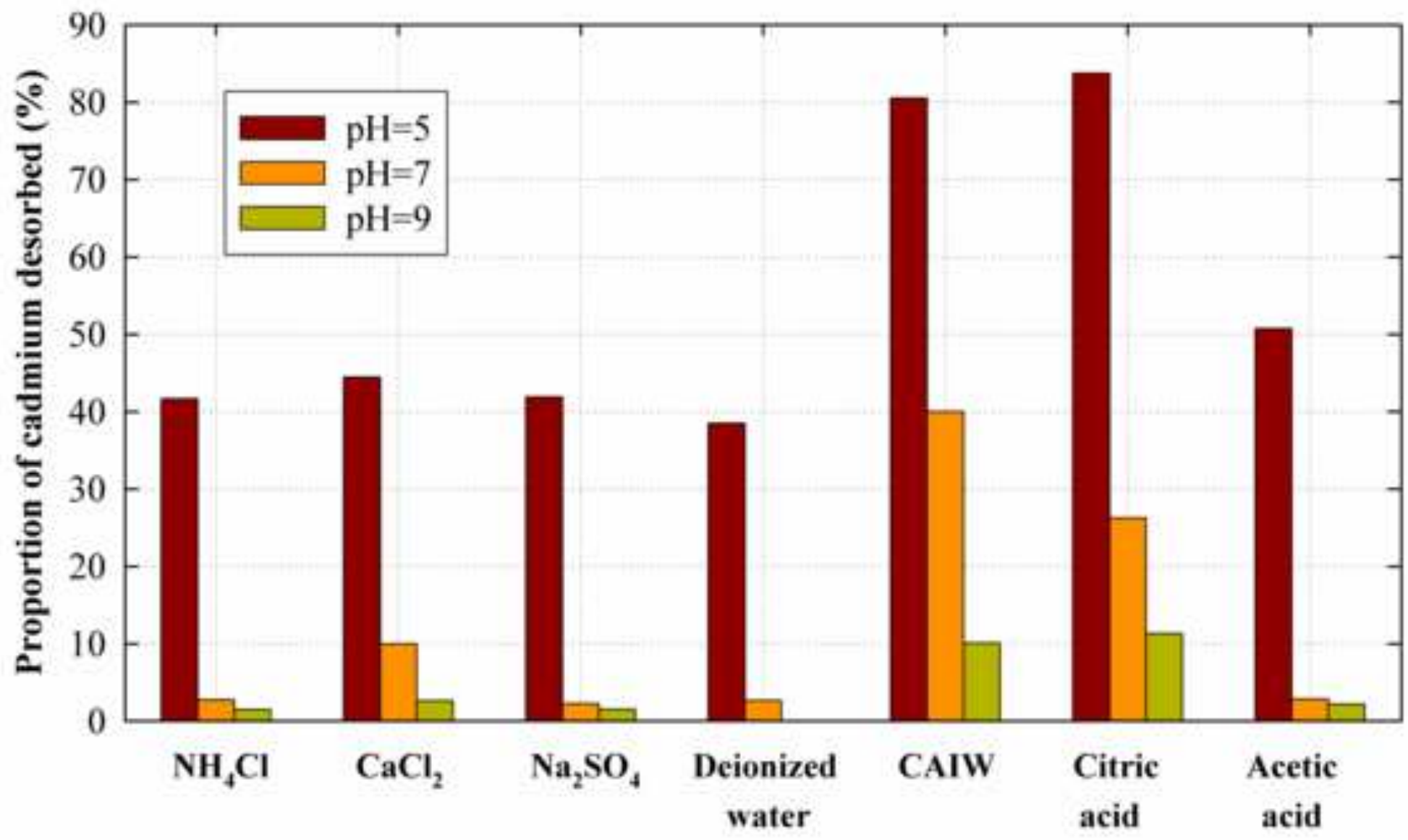

Figure 4. Effect of different constituents on cadmium desorption 


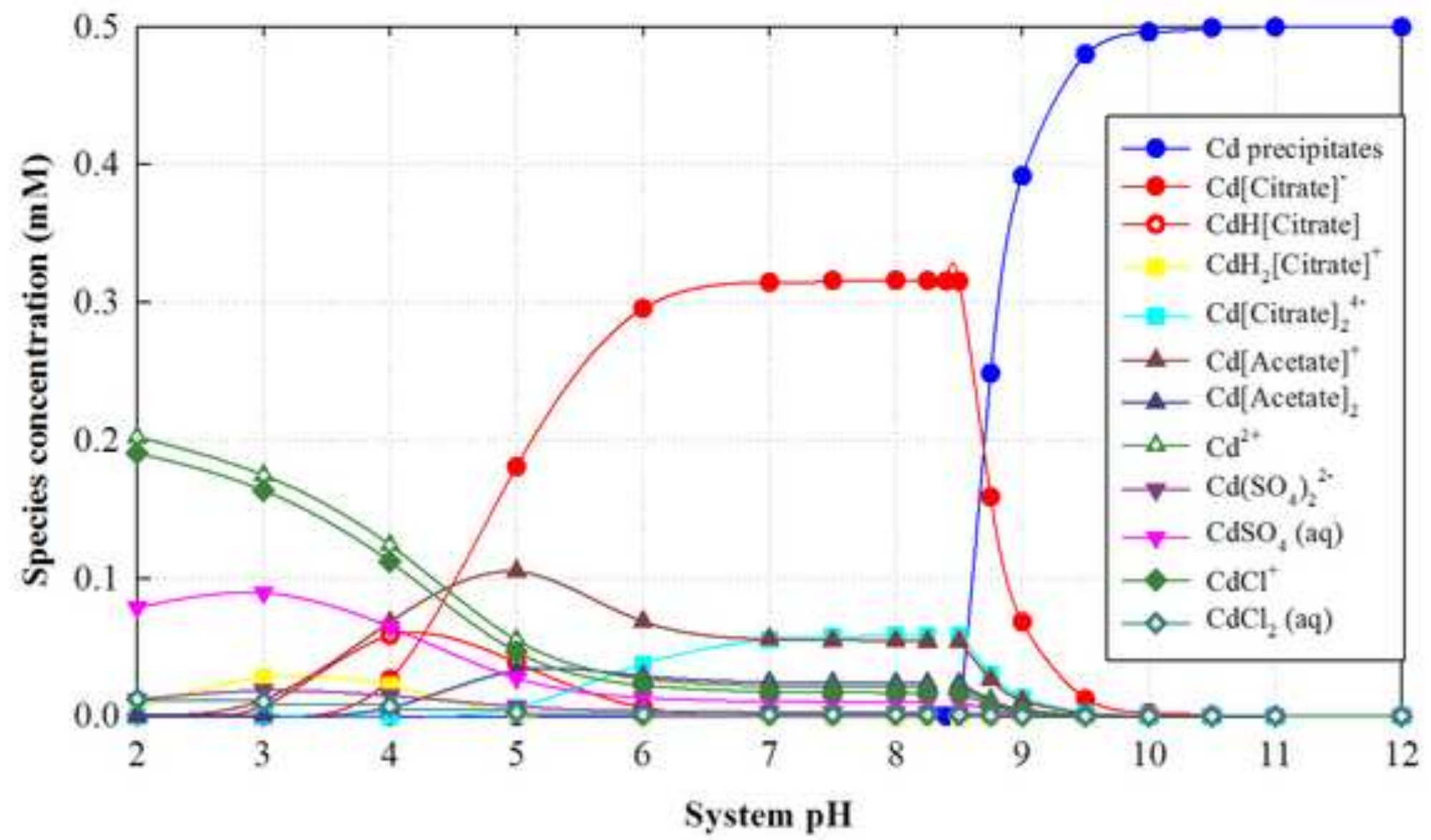

Figure 5 . Concentrations of different species in CAIW-Cd $(0.5 \mathrm{mM})$ system by MINTEQA2 